\title{
ON THE GRAVITY EQUATION OF TRADE: A CASE OF GERMANY
}

\author{
Jiří Mazurek
}

\section{Introduction}

The gravity model (or equation) of international trade is an economic analogy to Newton's Law of gravity. The economic version of this law assumes that international bilateral trade is directly proportional to 'sizes' of trading economies, and indirectly proportional to their distance. Gravity was introduced into economic theory by Tinbergen (1962), and later this pioneer work was followed by many other studies, see e.g. Anderson (1979; 2010), Bergstrand (1985), Deardoff (1998), Anderson and van Wincoop (2003), Helpman et al. (2008), or Bergstrand and Egger (2011). A concise review of gravity approach can be found e.g. in Anderson (2010) or Salvatici (2014).

Theoretical explanation of the gravity equation for aggregated or disaggregated trade can be found e.g. in Anderson (1979) or Chaney (2011). Trade in a real world is influenced not only by economic size and distance, but also by trade 'frictions' (trade costs or trade barriers) such as borders among countries, a different language and currency, colonial ties, free trade agreements, etc., these additional factors were incorporated into gravity models as well, see e.g. Deardoff (1998), Baier and Bergstrand (2009), Anderson (2010), Bergstrand and Egger (2011) or Salvatici (2014).

Gravity models theoretically explain the role of an economic size in bilateral trade flows at any scale (countries, regions, etc.); though the role of a distance is not well understood yet, see Disdier and Head (2008). Moreover, gravity applies to other socio-economic phenomena such as migration or direct foreign investments. Generally, according to Anderson (1979) or Chaney (2011), gravity models of trade can be considered the most successful empirical tools in economics.

The empirical evidence for gravity models is rather strong, as various studies report the coefficient of determination between 0.6 and
0.8. A meta-analysis of 1,467 estimates in 103 papers provided by Disdier and Head (2008) found $\alpha \approx \beta \approx \gamma \approx 1$ in relation (1) (see below). Remarkably, the coefficient $y$ has been stable (and close to one) for more than one century. A theoretical explanation of this result can be found e.g. in Chaney (2011).

Gravity model estimations are usually carried out for cross-sectional or panel data. However, countries all over the world form a very heterogeneous sample. There are countries with centuries of industrial tradition and export (the USA, the UK, Germany, etc.), countries that export aggressively in the last decades (Japan, Korea, China, etc.), and also a large number of developing countries whose exports are limited to articles such as bananas or cocoa beans. Moreover, a trade is a product of particular human action, and people living under different conditions and regimes simply cannot act in a similar way. Therefore, one should not expect international trade to be universally described or explained by one equation, model or a formula. To mix such different trade partners while looking for a general pattern (as in physics) makes little sense in economics. Hence, a more sensible approach might be the use of more homogenous sets of countries, such as developed (OECD) countries, Latin-American countries, etc.

This aforementioned approach is followed in this paper, where the gravity equation is used to model aggregate export's shares of one country (Germany) to its trading partners (importing countries).

As the gravity model is usually formulated in a multiplicative form, it is log-transformed into a linear equation and coefficients of a model are estimated by an appropriate regression method. A problem of a correct estimation of a gravity model is a broadly discussed issue, see e.g. Heckman (1979), Silva and Tenreyro (2006), 
Martínez-Zarzoso et al. (2007), Helpman et al. (2008), Baier and Bergstrand (2009), Egger (2010), Herrera and Baleix (2010) or Herrrera (2013). However, there is not a consensus on what the most appropriate regression estimation is in the case when assumptions of Ordinary Least Squares (OLS) method are violated, in particular, when a significant heteroscedasticity is present. Under such circumstances the Pseudo Poisson Maximum Likelihood (PPML) method, the Nonlinear Least Squares (NLS) method or the Feasible Generalized Least Squares (FGLS) methods were proposed by Silva and Tenreyro (2006) or Martínez-Zarzoso et al. (2007). Nevertheless, if assumptions of OLS are satisfied, it is the BLUE (Best Linear Unbiased Estimator) method.

The aim of the article is to examine how the aggregated gravity models fit the latest export data for Germany both without and with trade frictions. Germany was selected for this study because it is the $3^{\text {rd }}$ largest world exporter (behind the USA and China), and it ranks among the most developed countries of the world. It is suitably located in the middle of the continent surrounded by many trading partners in different distances; and last, but not least, the data for Germany can be considered accurate and reliable.

The paper is organized as follows: in section 1 Germany's export is briefly discussed, in section 2 the data is described, in sections 3 and 4 aggregate gravity models without and with frictions are presented along with their results. Conclusions follow at the end of the article.

\section{Germany's Export}

Germany belongs among countries with a positive balance of international trade in the long term. In 2014, the balance (export minus import) reached 217 billion Euros according to Statistisches Bundesamt (2015b). Commodity structure of export is rather stable in the last decade. The most important export items are transportation (cars, car parts, engines and aerial technology), instruments of electrical engineering, telecommunications technology, office technology and machinery; see Statistisches Bundesamt (2015a). Figure 1 provides more detailed commodity structure of export in 2014.

The most important trade partners of Germany are France, USA, UK, Netherlands and China (see also Appendix A). In 2014, $58 \%$ of Germany's export went to EU, $17 \%$ to Asia, $12 \%$ to Americas, $10 \%$ to non-EU European countries, 2\% to Africa and the rest $(0.3 \%)$ to Australia and Oceania according to Statistisches Bundesamt (2015b).

Germany is a federal parliamentary republic consisting of 16 constituent states. In 2014, the strongest exporting states were BadenWürttemberg (16\% of total Germany's export), North Rhine-Westphalia (15.9\%), Bavaria (14.9\%) and Lower Saxony (6.9\%). Around 85\% of export was a completed production, $5 \%$ semifinished production, and around $1 \%$ accounted for raw material. More detailed data including a structure of export by individual states can be found in Statistisches Bundesamt (2015b).

\section{Fig. 1: The commodity structure of Germany export in 2014 (in billion Euros)}

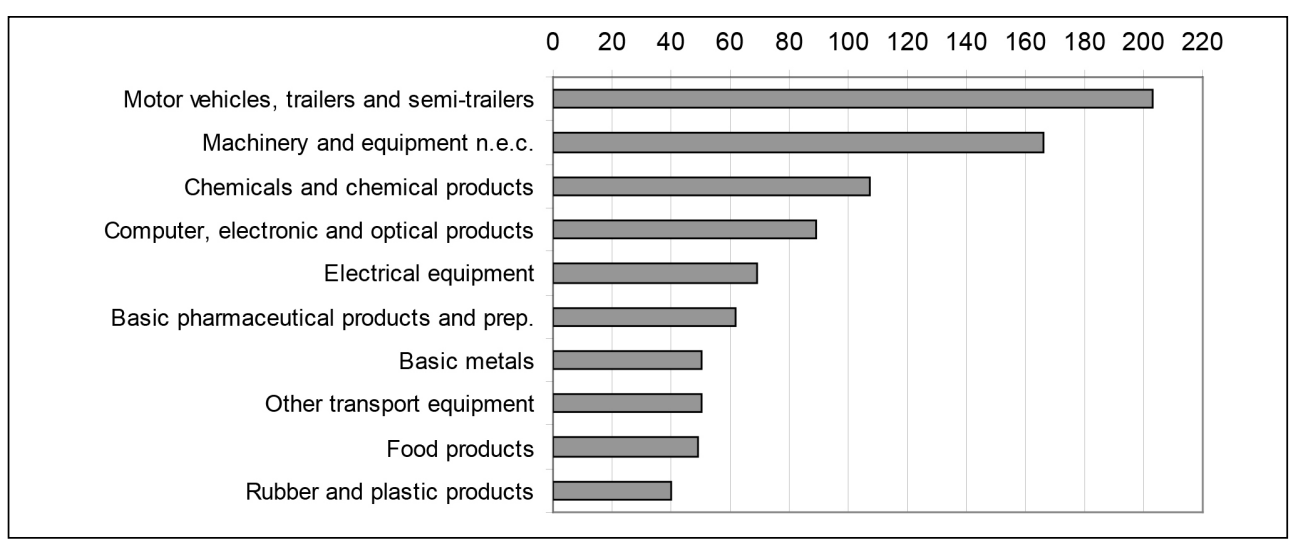




\section{Method and Data}

Germany's export is examined via aggregate gravity equations with and without frictions. These equations (models) are introduced and described in detail in the following two sections. As gravity equations have a multiplicative form, they were linearized by the logarithmic transformation. Then, linear regression was performed by the most suitable estimation method.

For the empirical investigation the following data was used:

- Importing partners' shares (in \%) of Germany's export for the year 2013 were obtained from Statistisches Bundesamt (2014). The data is provided in the form of a ranking of trading partners in the descending order. For this study the list of all countries was truncated and includes 66 main partners (from France to Qatar) with an individual share of import from Germany at least equal to $0.10 \%$, as the relative error of values lower than $0.10 \%$ would be inappropriately high (see a discussion at the end of section 4). These 66 countries comprise $97.6 \%$ of Germany's export.

- Distances between Germany and importing countries (in kilometers) were obtained from a distance calculator at Timeanddate (2013). The distance between two countries was defined as an air distance between their capital cities.

- GDP (PPP) in billions USD of importing countries were retrieved from the International Monetary Fund (2013).

- Other countries' data include their currency, a membership to Schengen area and an existence of joint borders with Germany.

The dependent variable in the models was importing partners' shares (in \%), other variables were considered independent. All data is provided in Appendix A. It should be noted that export shares and GDP (PPP in billion dollars) could be a subject of later revisions.

\section{Frictionless Gravity Model, Results and Discussion}

The standard gravity model (equation) of aggregate international trade usually takes the following form (Chaney, 2011):

$$
T_{i j}=k \frac{G D P_{i}^{\alpha} G D P_{j}^{\beta}}{d_{i j}^{\gamma}},
$$

where $T_{i j}$ is a trade from a country $i$ to a country $j, G D P_{i}$ denotes gross domestic product, $k$ is a positive coefficient, and $d_{i j}$ is a geographic distance of both countries.

Anderson (2010) assumes that supply $Y_{i}$ of a country $i$ is attracted by a demand $E_{j}$ of a country $j$, where $d_{i j}$ denotes a distance of both countries, and proposes the following frictionless and aggregate gravity model of trade:

$$
T_{i j}=\frac{Y_{i} E_{J}}{d_{i j}{ }^{2}}
$$

Also, in some alternative gravity models an income per capita (along with a population) of countries is used instead of supply and demand, and an error term is added on the right hand side of equations; see Anderson (1979):

$$
M_{i j}=\alpha Y_{i}^{\beta} Y_{j}^{\gamma} N_{i}^{\xi} N_{j}^{\varepsilon} d_{i j}^{\mu} U_{i j}
$$

In (3) $M_{i j}$ is the dollar flow of a given good from a country $i$ to a country $j, Y_{i}$ and $Y_{j}$ are incomes in both countries, $N_{i}$ and $N_{j}$ are their populations, and $U_{i j}$ is a log-normally distributed error term with $E\left(\ln U_{i j}\right)=0$.

In the last decades, more sophisticated models for disaggregated goods and with trade frictions were developed, see e.g. Anderson (2010) or Salvatici (2014).

In this paper the following aggregate frictionless gravity model for Germany's export shares is considered:

$$
E_{i}=k \frac{G D P_{i}^{\alpha}}{D I S T_{i}^{\beta}}
$$

In (4) $E_{i}$ denotes a share of Germany's export (in \%) to a country $i, G D P$ is a gross domestic product of an importing country $i$, $D I S T_{i}$ is a distance between country $i$ and Germany, and $\alpha, \beta$, and $k$ are coefficients.

Relation (4) simply states that an export rises when an importing country is closer and/ or richer. It should be noted that if absolute values of exports (e.g. in billions of USD) were considered in (4) instead of relative exports, then only the coefficient $k$ would change. 
For the regression analysis the relation (4) is reformulated in the following way:

$$
E_{j}=k \cdot G D P_{j}^{\alpha} \cdot D I S T_{j}^{\beta}
$$

Gravity equation is transformed logarithmically (all variables are positive) which yields:

$$
\ln E_{j}=\ln k+\alpha \cdot \ln G D P_{j}+\beta \ln D I S T_{j}
$$

The correlation matrix of variables in the model (6) is shown in Table 1. As it can be seen, correlation coefficients were not particularly high. Multicollinearity in the model (6) was examined via the Variance Inflation Factor (VIF), $V I F_{i}=1 /\left(1-R_{i}^{2}\right)$, where $R_{i}^{2}$ is the proportion of variance in the $i$-th independent variable associated with other independent variables in a model, see O'Brian (2007). A rule of thumb states that for values of VIF larger than 10 multicollinearity of a model can be considered a serious problem. In the model (6) VIF of both explanatory variables was only around 1.3.
For the regression model (6) the data from Appendix A was used. The regression was performed via statistical software Gretl. Residuals were examined for exogeneity, normality and heteroscedasticity. All assumptions of OLS were satisfied with an exception of heteroscedasticity associated with the logarithm of GDP, where the null hypothesis (homoscedasticity) could be rejected by White's test at $p=0.04$ level. Therefore, Gretl's builtin OLS with the corrected heteroscedasticity method (which incorporates weighted least squares method) was used for the estimation. Results are reported in Table 2.

As it can be seen from Table 2, both regressors (logs of GDP and distance) were found significant at 0.01 level. As expected, regression coefficient for logarithm of distance is negative, and the coefficient for logarithm of GDP is positive, both coefficients are close to 1, which is in accord with other studies' findings. The adjusted coefficient of determination $R^{2}=0.742$, which is within a range of $0.6-0.8$ was found in other similar studies as well.

Tab. 1: The correlation matrix of variables from the model (6)

\begin{tabular}{c|c|c|c} 
& Ln(export) & Ln(Dist) & $\operatorname{Ln}($ GDP) \\
\hline $\operatorname{Ln}($ export) & 1 & -0.291 & 0.525 \\
\hline $\operatorname{Ln}($ Dist) & & 1 & 0.506 \\
\hline $\operatorname{Ln}(\mathrm{GDP})$ & & & 1 \\
\hline
\end{tabular}

Source: own

\section{Tab. 2: The frictionless gravity model - estimation results}

\begin{tabular}{c|c} 
Regressor/method & OLS with c. $\mathbf{h}$. \\
\hline Const. & $1.030(0.554)^{*}$ \\
\hline $\operatorname{Ln}($ Dist $)$ & $-0.903(0.081)^{\star * *}$ \\
\hline $\operatorname{Ln}($ GDP $)$ & $0.896(0.071)^{* *}$ \\
\hline No. of observ. & 66 \\
\hline
\end{tabular}

Notes: Standard errors in brackets. * significant at $10 \% ;{ }^{* *}$ significant at $5 \% ;{ }^{* \star \star}$ significant at $1 \%$ 


\section{Gravity Model with Frictions, Results and Discussion}

Frictions of any kind (borders, a different language or currency, colonial ties, legislative, culture, religion, etc.), which influence real trade, can be incorporated into the gravity models as well. In this paper the following trade frictions as explanatory variables were examined:

- Adjacency (A): the existence of national borders is considered one of the most important frictions in international trade. According to Anderson (2010), cross-border trade is typically reduced by a factor of $1 / 20$ to $1 / 3$ to its potential value. However, when a trade is carried out between countries without common border, it is reduced even more significantly.

- Currency (C): different currency might diminish trade volumes due to exchange rates uncertainty; it may require additional transaction costs as well.

- Location in the Schengen area (LISA): the Schengen area, established in 1995, abolished internal border controls and allowed free transfer of people within the area. This could affect trade volumes within the Schengen favorably.
All these trade friction variables are dummy (binary) variables with values 0 or 1 , see Table 3. Also several other trade frictions were considered at the beginning of the study, such as democracy index of importing countries, length of common borders with Germany, geographic location of importing countries (not just their distance), or the fact whether transportation of goods is managed on a land or a sea, but preliminary results showed these variables were not statistically significant in the examined models, or were highly correlated with other independent variables, so they were eliminated from the model. Nevertheless, though only three variables associated with trade frictions were left in the model, its explanatory power was very high (see results at the end of this section).

The friction gravity model has the following form:

$$
\begin{aligned}
& E_{i}(\%)=k \cdot G D P_{i}^{\alpha} \cdot D I S T_{i}^{\beta} . \\
& \cdot \operatorname{EXP}\left(C_{i}^{\gamma} \cdot A_{i}^{\delta} \cdot L I S A_{i}^{\eta}\right)
\end{aligned}
$$

Log-transform of (7) yields:

$$
\begin{aligned}
& \ln \left(E_{i}\right)=\ln k+\alpha \ln G D P_{i}+\beta \ln D I S T_{i}+ \\
& +\gamma C_{i}+\delta A_{i}+\eta L I S A_{i}
\end{aligned}
$$

\section{Tab. 3: Selected trade frictions}

\begin{tabular}{l|c|c}
\multicolumn{1}{c|}{ Trade friction } & Acronym & Values \\
\hline The same currency & C & yes: 0, no: 1 \\
\hline Shared borders with Germany & A & yes: 0, no: 1 \\
\hline Location in the Schengen area & LISA & yes: 0, no: 1 \\
\hline
\end{tabular}

The correlation matrix of all regressors in (8) is provided in Table 4. Variance Inflation Factor (VIF) for all explanatory variables was found lower than 4 , with a maximum value of 3.24 for LISA. Therefore, multicollinearity of the model (8) did not constitute a problem.

Again, assumptions regarding the use of OLS were examined, with the result OLS is an appropriate estimation method with an exception of heteroscedasticity of In(GDP), so OLS with corrected heteroscedasticity in Gretl was performed again. Estimation results are shown in Table 5.
All variables associated with trade frictions were found statistically significant, though only adjacency was found statistically significant at 0.01 level. Moreover, regression coefficients of all friction variables were found negative as expected. According to coefficients' values, the most important trade friction is adjacency - countries not bordering with Germany import significantly less (by a factor of 1.6) than Germany's neighbors. Adjusted coefficient of determination for the model is very high, $R^{2}=0.92$, which indicates the model is appropriate and possess high explanation power. 
Tab. 4: Correlation of explanatory variables in the model (8)

\begin{tabular}{l|c|c|c|c|c} 
& Ln(DIST) & Ln(GDP) & A & C & LISA \\
\hline $\operatorname{Ln}(\mathrm{DIST})$ & 1 & 0.506 & 0.545 & 0.493 & 0.726 \\
\hline $\operatorname{Ln}(\mathrm{GDP})$ & & 1 & 0.077 & 0.239 & 0.364 \\
\hline $\mathrm{A}$ & & & 1 & 0.334 & 0.562 \\
\hline $\mathrm{C}$ & & & & 1 & 0.655 \\
\hline LISA & & & & & 1 \\
\hline
\end{tabular}

Source: own

\section{Tab. 5: Estimation results of the model (8)}

\begin{tabular}{l|c}
\multicolumn{1}{c|}{ Regressors } & OLS with c. $\mathbf{h .}$ \\
\hline const. & $0.416(0.494)$ \\
\hline Ln(Dist) & $-0.695(0.088)^{\star \star \star}$ \\
\hline $\operatorname{Ln}(\mathrm{GDP})$ & $0.877(0.040)^{\star \star *}$ \\
\hline $\mathrm{A}$ & $-0.495(0.135)^{\star \star *}$ \\
\hline $\mathrm{C}$ & $-0.351(0.135)^{\star \star}$ \\
\hline LISA & $-0.328(0.171)^{\star}$ \\
\hline No. of observ. & 66 \\
\hline
\end{tabular}

Notes: Standard errors in brackets. * significant at $10 \%$; ${ }^{* *}$ significant at $5 \% ;{ }^{* * *}$ significant at $1 \%$

Arguably, the most important determinants of export volumes (or shares) are distance between trading countries and a value of GDP of importing countries (countries' wealth). However, when export is low, influence of other factors may be not negligible. For example, one large government or private contract (such as opening of Bosch's subsidiary in Kenya during 2014), may change the export data substantially. This can be easily illustrated by the Statistische Bundesamt $(2013 ; 2014)$ data on Germany's exports from 2012 and 2013. The change in export volumes between years 2012 and 2013 for the top ten importers from Germany (from France to Belgium) was about $2 \%$ on average, but for countries ranked from the $101^{\text {th }}$ to the $110^{\text {th }}$ place (from El Salvador to Zambia) this year-to-year change amounted to $46 \%$ on average. A question arises, whether such data can be considered more than just a noise.

In this study only the data for top 66 countries with at least $0.10 \%$ share of Germany's export was examined, but its total share of export is
$97.6 \%$. Remaining 173 countries sum up to only $2.4 \%$ of Germany's export, but, if used, they would form a majority of the dataset. That is the main reason why they were left out of this study. However, if averaged data over some longer period (five or ten years) demonstrate more stability, then it might be possible to include these countries as well.

\section{Conclusions}

In this study Germany's latest aggregate export shares with the use of a gravity equation without and with trade frictions were examined. This is a slightly different approach from a standard methodology where trade volumes are studied with the use of cross-sectional or panel data. Also, only data for countries with import shares from Germany exceeding $0.10 \%$ were employed, as countries with lower trade volumes are susceptible to large year-toyear fluctuations, which affect the estimation by gravity equation negatively. The use of averaged data over longer periods might be more appropriate as elimination or smoothing 
of data fluctuations may result in much better statistical performance of gravity models in general.

One of main findings of this study is that the frictionless gravity model is very successful in fitting the data with adjusted coefficient of determination $R^{2}$ equal to 0.74 . As expected, export shares were found (roughly) directly proportional to a GDP of an importer and negatively proportional to importers' distance.

More interesting findings concern the gravity model with frictions, namely adjacency, currency and location in the Schengen area. This model fitted the data even better than frictionless model, with the adjusted coefficient of determination $R^{2}$ as high as 0.92 . All frictions were found statistically significant at 0.10 level, and their regression coefficients were found negative, which means they were factors contributing to the trade decrease indeed, with (not)adjacency as the most important trade barrier itself.

The border effect, which diminishes trade substantially even in cases where no borders are physically present (as in the EU), is still considered puzzling, see Anderson (2010). One possible explanation, somewhat overlooked in the literature, might rest in information deficiency. To trade, information about demand and supply for particular goods must be available to both potential trade partners. But subjects of trade (Germany's exporters, for example) are better informed about situation at their home market in Germany than about the situation at neighboring markets (for example in Belgium), because they primarily acquire information through home German media (TV, newspapers, Internet, etc., and also through personal contact). However, near borders with Belgium German exporters can acquire information from Belgian sources, and thus could be, at least partially, informed about its market. This information acquisition is even more reduced when there is no border between both countries (no adjacency), as information can be shared only indirectly (by Internet, satellite TV) or by (not so often) personal contact. That is why trade with a foreign subject is less likely.

This paper was supported by the Ministry of Education, Youth and Sports Czech Republic within the Institutional Support for Long-term Development of a Research Organization in 2015.

\section{References}

Anderson, J. E. (2010). The Gravity model (NBER Working Paper No. 16576). Cambridge, MA: National Bureau of Economic Research.

Anderson, J. E. (1979). A theoretical foundation for the gravity equation. American Economic Review, 69(1), 106-116.

Anderson, J. E., van Wincoop, E. (2003), Gravity with Gravitas: A solution to the Border Puzzle. American Economic Review, 93(1), 170-192. doi:10.3386/w8079.

Baier, S. L., \& Bergstrand, J. H. (2009). Bonus Vetus OLS: A Simple Method for Approximating International Trade-Cost Effects using the Gravity Equation. Journal of International Economics, 77(1), 77-85. doi:10.1016/j.jinteco.2008.10.004.

Bergstrand, J. H. (1985). The Gravity Equation in International Trade: Some Microeconomic Foundations and Empirical Evidence. Review of Economics and Statistics, 67(3), 474-481.

Bergstrand, J. H., Egger, P. (2011). Gravity Equations and Economic Frictions in the World Economy. Palgrave Handbook of International Trade, 532-570.

Chaney, T. (2011). The gravity equation in international trade: an explanation (NBER Working Papers No. 19285). Cambridge, MA: National Bureau of Economic Research.

Deardorff, A. (1998). Determinants of Bilateral Trade: Does Gravity Work in a Neoclassical World? The Regionalization of the World Economy. 7-32.

Disdier, A., Head, K. (2008). The puzzling persistence of the distance effect on bilateral trade. Review of Economics and Statistics, 90(1), 37-41. doi:10.1162/rest.90.1.37.

Egger, P. (2000). A Note on the proper econometric specification of the gravity equation. Economic Lettters, 66(1), 25-31. doi:10.1016/S0165-1765(99)00183-4.

Heckman, J. J. (1979). Sample selection bias as a specification error. Econometrica, 47(1), 153-61. doi:10.2307/1912352.

Helpman, E., Melitz, M. J., \& Rubinstein, Y. (2008). Estimating Trade Flows: Trading Partners and Trading Volumes. Quarterly Journal of Economics, 123(2), 441-487. doi:10.1162/qjec.2008.123.2.441.

Herrera, E. G. (2013). Comparing alternative methods to estimate gravity models of bilateral trade. Empirical Economics, 44(3), 1087-1111. doi:10.1007/s00181-012-0576-2. 
Herrera, E. G., \& Baleix, J. M. (2010). Are estimation techniques neutral to estimate gravity equations? An application to the impact of EMU on third countries' export. Retrieved February 4, 2014, from http://www.ub.edu /jei/ papers/GOMEZ-MILGRAM.pdf.

International Monetary Fund. (2013). IMF Data. Retrieved October 12, 2013, from http:// www.imf.org.

Martínez-Zarzoso I., Nowak-Lehmann, F., \& Vollmer, S. (2007). The log of gravity revisited (CEGE Discussion Paper No. 64). Göttingen: University of Göttingen.

O'Brian, R. M. (2007). A Caution Regarding Rules of Thumb for Variance Inflation Factor. Quality and Quantity, 41(5), 673-690. doi:10.1007/s11135-006-9018-6.

Salvatici, L. (2014). The gravity model in international trade (AGRODEP Technical Notes No. TN-04). Washington, DC: International Food Policy Research Institute.

Santos Silva, J. M., \& Tenreyro, S. (2006). The Log of Gravity. The Review of Economics and Statistics, 88(4), 641-658. doi:10.1162/ rest.88.4.641.

Statistisches Bundesamt. (2013). Foreign Trade - Ranking of Germany's trading partners in foreign trade. Retrieved April 28, 2014, from https://www.destatis.de/EN/FactsFigures/ National EconomyEnvironment/ForeignTrade/ TradingPartners.
Statistisches Bundesamt. (2014). Foreign Trade - Ranking of Germany's trading partners in foreign trade. Retrieved April 22, 2014, from https://www.destatis.de/EN/FactsFigures/ National EconomyEnvironment/ForeignTrade/ TradingPartners.

Statistisches Bundesamt. (2015a). The main German export product: motor vehicles. Retrieved December 5, 2015, from https://www.destatis.de/EN/FactsFigures/ NationalEconomyEnvironment /ForeignTrade/ TradingGoods/Current.html.

StatistischesBundesamt.(2015b). Statistisches Jahrbuch 2015. Retrieved December 6, 2015, from https://www.destatis.de/DE/Publikationen/ StatistischesJahrbuch/StatistischesJahrbuch2015. pdf? blob=publicationFile.

Timeanddate. (2013). Calculators and Timers. Retrieved October 24, 2013, from http:// www. timeanddate.com/worldclock/distance.html.

Tinbergen, J. (1962). Shaping the World Economy: Suggestions for an International Economic Policy. New York: The Twentieth Century Fund.

Mgr. Jiří Mazurek, Ph.D. Silesian University in Opava School of Business Administration in Karviná Department of Mathematical Methods in Economics mazurek@opf.slu.cz 


\section{Ekonomie}

\section{Appendix A: The data for the gravity model with frictions - Part 1}

\begin{tabular}{|c|c|c|c|c|c|c|}
\hline Country & Export share (\%) & Dist. (km) & $\begin{array}{l}\text { GDP PPP } \\
\text { (bil. USD) }\end{array}$ & C & LISA & A \\
\hline 001 France & 9.146 & 879 & $2,534.5$ & 0 & 0 & 0 \\
\hline 002 United States & 8.174 & 6,727 & $16,768.1$ & 1 & 1 & 1 \\
\hline 003 United Kingdom & 6.906 & 932 & $2,320.4$ & 1 & 1 & 1 \\
\hline 004 Netherlands & 6.492 & 577 & 780.3 & 0 & 0 & 0 \\
\hline 005 China & 6.121 & 7,377 & $16,149.1$ & 1 & 1 & 1 \\
\hline 006 Austria & 5.148 & 523 & 376.7 & 0 & 0 & 0 \\
\hline 007 Italy & 4.871 & 1,183 & $2,035.4$ & 0 & 0 & 1 \\
\hline 008 Switzerland & 4.293 & 752 & 432.0 & 1 & 0 & 0 \\
\hline 009 Poland & 3.885 & 520 & 896.8 & 1 & 0 & 0 \\
\hline 010 Belgium & 3.882 & 651 & 455.0 & 0 & 0 & 0 \\
\hline 011 Russian Federation & 3.275 & 1,616 & $3,491.6$ & 1 & 1 & 1 \\
\hline 012 Spain & 2.868 & 1,870 & $1,488.8$ & 0 & 0 & 1 \\
\hline 013 Czech Republic & 2.843 & 280 & 287.6 & 1 & 0 & 0 \\
\hline 014 Turkey & 1.955 & 2,042 & $1,443.5$ & 1 & 1 & 1 \\
\hline 015 Sweden & 1.894 & 813 & 418.2 & 1 & 0 & 1 \\
\hline 016 Hungary & 1.601 & 691 & 229.6 & 1 & 0 & 1 \\
\hline 017 Japan & 1.562 & 8,940 & $4,667.6$ & 1 & 1 & 1 \\
\hline 018 Denmark & 1.449 & 356 & 240.9 & 1 & 0 & 0 \\
\hline 019 Korea Rep. & 1.322 & 8,150 & $1,697.0$ & 1 & 1 & 1 \\
\hline 020 Brazil & 1.033 & 9,573 & $3,012.8$ & 1 & 1 & 1 \\
\hline 021 Slovakia & 0.973 & 554 & 144.0 & 0 & 0 & 1 \\
\hline 022 United Arab Emirates & 0.906 & 4,641 & 570.6 & 1 & 1 & 1 \\
\hline 023 Romania & 0.882 & 1,297 & 371.2 & 1 & 1 & 1 \\
\hline 024 Saudi Arabia & 0.844 & 4,175 & $1,553.1$ & 1 & 1 & 1 \\
\hline 025 India & 0.837 & 5,793 & $6,776.0$ & 1 & 1 & 1 \\
\hline 026 Mexico & 0.818 & 9,741 & $2,058.9$ & 1 & 1 & 1 \\
\hline 027 Canada & 0.807 & 6,146 & $1,518.4$ & 1 & 1 & 1 \\
\hline 028 Australia & 0.785 & 16,062 & $1,052.6$ & 1 & 1 & 1 \\
\hline 029 South Africa & 0.780 & 8,789 & 662.6 & 1 & 1 & 1 \\
\hline 030 Norway & 0.750 & 840 & 328.0 & 1 & 0 & 1 \\
\hline 031 Finland & 0.747 & 1,109 & 218.3 & 0 & 0 & 1 \\
\hline 032 Portugal & 0.582 & 2,315 & 268.8 & 0 & 0 & 1 \\
\hline 033 Singapore & 0.577 & 9,928 & 425.3 & 1 & 1 & 1 \\
\hline 034 Taiwan & 0.538 & 8,971 & 970.9 & 1 & 1 & 1 \\
\hline 035 Hong Kong & 0.514 & 8,767 & 382.5 & 1 & 1 & 1 \\
\hline 036 Luxembourg & 0.507 & 601 & 48.5 & 0 & 0 & 0 \\
\hline 037 Ireland & 0.500 & 1,320 & 213.3 & 0 & 1 & 1 \\
\hline 038 Ukraine & 0.492 & 1,210 & 392.5 & 1 & 1 & 1 \\
\hline
\end{tabular}




\begin{tabular}{|c|c|c|c|c|c|c|}
\hline Country & Export share (\%) & Dist. (km) & $\begin{array}{l}\text { GDP PPP } \\
\text { (bil. USD) }\end{array}$ & C & LISA & A \\
\hline 039 Malaysia & 0.439 & 9,620 & 693.6 & 1 & 1 & 1 \\
\hline 040 Greece & 0.433 & 1,804 & 278.0 & 0 & 0 & 1 \\
\hline 041 Slovenia & 0.375 & 724 & 58.7 & 0 & 0 & 1 \\
\hline 042 Thailand & 0.359 & 8,615 & 964.5 & 1 & 1 & 1 \\
\hline 043 Israel & 0.329 & 2,851 & 257.5 & 1 & 1 & 1 \\
\hline 044 Indonesia & 0.286 & 10,779 & 2,389.0 & 1 & 1 & 1 \\
\hline 045 Argentina & 0.258 & 11,886 & 927.9 & 1 & 1 & 1 \\
\hline 046 Chile & 0.255 & 12,504 & 395.6 & 1 & 1 & 1 \\
\hline 047 Bulgaria & 0.242 & 1,320 & 119.6 & 1 & 1 & 1 \\
\hline 048 Lithuania & 0.226 & 823 & 75.4 & 1 & 0 & 1 \\
\hline 049 Egypt & 0.218 & 2,892 & 909.8 & 1 & 1 & 1 \\
\hline 050 Belarus & 0.209 & 958 & 166.8 & 1 & 1 & 1 \\
\hline 051 Kazakhstan & 0.197 & 4,701 & 395.5 & 1 & 1 & 1 \\
\hline 052 Algeria & 0.189 & 1,928 & 522.6 & 1 & 1 & 1 \\
\hline 053 Croatia & 0.187 & 769 & 86.6 & 1 & 1 & 1 \\
\hline 054 Vietnam & 0.169 & 8,342 & 475.0 & 1 & 1 & 1 \\
\hline 055 Iran & 0.168 & 3,514 & $1,244.3$ & 1 & 1 & 1 \\
\hline 056 Philippines & 0.158 & 9,880 & 643.1 & 1 & 1 & 1 \\
\hline 057 Estonia & 0.154 & 1,045 & 34.4 & 0 & 0 & 1 \\
\hline 058 Morocco & 0.146 & 2,610 & 241.7 & 1 & 1 & 1 \\
\hline 059 Serbia & 0.144 & 1,002 & 89.7 & 1 & 1 & 1 \\
\hline 060 Colombia & 0.133 & 9,430 & 602.0 & 1 & 1 & 1 \\
\hline 061 Latvia & 0.130 & 848 & 46.5 & 1 & 0 & 1 \\
\hline 062 Iraq & 0.127 & 3,269 & 499.6 & 1 & 1 & 1 \\
\hline 063 Nigeria & 0.122 & 4,848 & 972.6 & 1 & 1 & 1 \\
\hline 064 Kuwait & 0.121 & 3,826 & 275.4 & 1 & 1 & 1 \\
\hline 065 Tunisia & 0.121 & 1,766 & 119.7 & 1 & 1 & 1 \\
\hline 066 Qatar & 0.115 & 4,395 & 298.4 & 1 & 1 & 1 \\
\hline
\end{tabular}




\section{Abstract}

\section{ON THE GRAVITY EQUATION OF TRADE: A CASE OF GERMANY}

\section{Jiří Mazurek}

Gravity models (equations) of trade belong among the most successful empirical tools in the modern economics since their first economic applications in the yearly 1960s. They assume that bilateral trade is directly proportional to "economic sizes" (usually described in terms of GDP or income) of both trading partners and inversely proportional to their distance. The aim of this study was to examine Germany's latest (2012) yearly aggregate exports to its major international partners by a gravity equation without and with selected trade frictions including a geographical adjacency (the so called border effect), an influence of the same or different currency (Euro), and a location in the Schengen Area, the zone of a free movement of persons. Gravity models both without and with selected trade frictions fitted the data well, while the model with frictions performed significantly better. The adjacency was found the most important single trade friction, the location in the Schengen Area appeared to be the least important friction (but it was still statistically significant). Other feasible trade frictions, such as border length, a location in Europe or democracy index were examined too, but their effect on the trade was rather negligible. A possible explanation of the border effect, based on information deficiency, is included in the study as well. Furthermore, it was observed that yearly Germany's exports data are susceptible to large year-to-year fluctuations especially for countries with low imports. Therefore, using averaged data over five or ten years long periods might be more appropriate.

Key Words: Export, Germany, gravity equation, international trade, trade frictions.

JEL Classification: C51, F14, F17.

DOI: 10.15240/tul/001/2016-3-002 